\title{
Lung Cancer Mortality
}

\author{
Geographic Distribution in the \\ United States for 1948-1949
}

\begin{abstract}
By ERWIN F. HOFFMAN, M.D., M.P.H., and ALEXANDER G. GILLIAM, M.D., Dr.P.H.
\end{abstract}
$\mathrm{D}$ ATA on geographic variation within the United States in mortality recorded from cancer of a number of sites, including cancer of the lung and pleura, have been published for the period 1930-32 by Gover (1). At that time deaths were allocated to the State in which death occurred rather than to place of residence. A study by the Bureau of the Census (2), however, indicated that a majority of the nonresident cancer deaths represented movement within States rather than between States. For this reason, Gover's comparisons between States were valid, but they could not be extended to urban-rural comparisons within States and could not directly take into account State differences in urbanization. Gover, however, did demonstrate for respiratory cancer, as well as for cancer of several other sites, that rates were

Dr. Hoffman, now assigned to the Bureau of Prisons, Department of Justice, as medical officer at the Medical Center for Federal Prisoners, Springfield, Mo., was formerly epidemiologist with the Epidemiology Section, National Cancer Institute, Public Health Service. Dr. Gilliam has been head of the Epidemiology Section since 1948. His previous assignments in the field of epidemiology have included positions at Johns Hopkins University School of Hygiene and Public Health and at the University of Michigan School of Public Health. highest in the States having the greatest portion of population living in urban areas. Since then, there has been abundant evidence from other countries that mortality from cancer of the lung is greater in urban than in rural areas (3-5) Since no direct comparisons of urban and rural rates are available for the United States, it is the purpose of this paper to present State rates adjusted for residence (urban-rural) in addition to age, race, and sex.

\section{Material and Methods}

The figures presented in this report were computed from basic death certificate data taken from special tabulations supplied by the National Office of Vital Statistics, Public Health Service. For 1948, cancer of the lung comprises International List numbers $47 \mathrm{~b}, \mathrm{c}, \mathrm{d}$, and $\mathrm{e}$, and for 1949, numbers 162 and 163. Populations employed are those of the 1950 census. Urban population is that of the 1940 census definition and generally comprises those persons living in places of 2,500 or more people. Deaths were allocated to urban and rural categories according to the urban-rural status of the population in 1940. Use of the 1940 population status is not believed to introduce any important error in allocation of deaths within this broad urban-rural classification. The error would, however, be material if allocation were attempted on any finer division of the urban 
population, short of using individual places. ('The National Office of Vital Statistics, in studying urban-rural allocation of births, finds, in addition, that the overstatement for urban areas averages about 6 percent and that the understatement for rural areas averages 10 percent (6). A similar, but less pronounced, bias probably also operates in allocation of deaths.)

For comparison between States, adjustments are made by the indirect method, and rates are expressed in terms of the standardized mortality ratio (SMR), which has been so usefully employed in reports by the Registrar General of England and Wales. The SMR was computed as follows: The age, race, sex, and residence (urban-rural) specific rates for the entire United States were applied to the appropriate State populations to find the number of deaths expected in each State if United States rates prevailed; the number of deaths recorded in each State was then divided by the number of deaths expected, as obtained for each population category, and the quotient was multiplied by 100 . The SMR is thus a ratio which takes account of the age, race, sex, and residence (urban-rural) composition of each State's population. The State rate, adjusted for these factors by the indirect method, may therefore be obtained by multiplying the State SMR by the total United States rate. In this sense, then, although strictly speaking the SMR is a ratio and not a rate, it may be interpreted numerically as a standardized rate that is expressed as a percent of the total United States rate.
The population and the number of deaths in the various race, sex, and residence categories are given in table 1. Even with a 2-year experience, substantial numbers of deaths for rate computations are available only for the white population, both urban and rural, and for the nonwhite urban male population.

\section{Geographic Distribution, 1948-49}

In table 2 are given the age, race, and sex specific rates for residents of urban and rural areas of the entire United States. It is observed that, with the broad definition of urban used here, the mortality recorded is substantially greater for urban than for rural residents in all race and sex groups. The excess urban rate is more pronounced among males than among females, however. These differences are in general conformity with those recorded for white persons in England (3), Denmark (4), and Norway $(5)$. It is not possible with data presently available here or elsewhere to determine whether they are due to occupational, environmental, economic, diagnostic, or other factors, although there has been considerable speculation regarding reasons for such differences.

It is also observed in table 2 that in each sex and residence category the total rates for the white population exceed those recorded for the nonwhite. The difference in rates between the race groups is more pronounced, however, among males than among females.

In connection with the difference in rates for the two race groups, comparisons of age

Table 1. Urban and rural population (1950) and deaths from cancer of the lung (1948-49) in the United States, according to race and sex

\begin{tabular}{|c|c|c|c|c|c|c|}
\hline \multirow{2}{*}{ Race and sex } & \multicolumn{2}{|c|}{ Urban } & \multicolumn{2}{|c|}{ Rural } & \multicolumn{2}{|c|}{ United States } \\
\hline & Population & Deaths & Population & Deaths & Population & Deaths \\
\hline $\begin{array}{l}\text { White: } \\
\quad \text { Male_- } \\
\quad \text { Female }\end{array}$ & $\begin{array}{l}38,697,282 \\
40,970,582\end{array}$ & $\begin{array}{r}18,201 \\
4,358\end{array}$ & $\begin{array}{l}28,431,910 \\
26,842,254\end{array}$ & $\begin{array}{l}6,711 \\
1,888\end{array}$ & $\begin{array}{l}67,129,192 \\
69,812,836\end{array}$ & $\begin{array}{r}24,912 \\
6,246\end{array}$ \\
\hline $\begin{array}{l}\text { Nonwhite: } \\
\text { Male } \\
\text { Female }\end{array}$ & $\begin{array}{l}4,419,988 \\
4,839,612 \\
\end{array}$ & $\begin{array}{r}1,244 \\
326\end{array}$ & $\begin{array}{l}3,284,059 \\
3,211,674\end{array}$ & $\begin{array}{r}354 \\
98\end{array}$ & $\begin{array}{l}7,704,047 \\
8,051,286\end{array}$ & $\begin{array}{r}1,598 \\
424 \\
\end{array}$ \\
\hline Total & $88,927,464$ & 24,129 & $61,769,897$ & 9,051 & $150,697,361$ & 33,180 \\
\hline
\end{tabular}


specific rates are of considerable interest. In the urban population, age specific death rates for the nonwhite group exceed or approximately equal the rates for the white group up to age 55 years among males and up to age 60 years among females. Among older persons, rates for the white population greatly exceed the rates for the nonwhite. This tendency is also evident, although less pronounced, in the rural population. It is therefore clear that the greater overall mortality in the white population is due to excessive rates for older persons. No reason

Table 2. Average annual age, race, and sex specific mortality rates per $1,000,000$ population for cancer of the lung among the urban and rural population of the United States, 1948-49 ${ }^{1}$

\begin{tabular}{|c|c|c|c|c|c|c|c|c|}
\hline \multirow{3}{*}{ Age (years) } & \multicolumn{4}{|c|}{ Urban $^{2}$} & \multicolumn{4}{|c|}{ Rural } \\
\hline & \multicolumn{2}{|c|}{ White } & \multicolumn{2}{|c|}{ Nonwhite } & \multicolumn{2}{|c|}{ White } & \multicolumn{2}{|c|}{ Nonwhite } \\
\hline & Male & Female & Male & Female & Male & Female & Male & Female \\
\hline $\begin{array}{l}\text { Total crude rate } \\
\text { Total adjusted rate }\end{array}$ & $\begin{array}{l}\text { 235. } 2 \\
223.4\end{array}$ & $\begin{array}{l}53.2 \\
47.4\end{array}$ & $\begin{array}{l}140.7 \\
169.1\end{array}$ & $\begin{array}{l}33.7 \\
41.6\end{array}$ & $\begin{array}{r}118.0 \\
123.23\end{array}$ & $\begin{array}{l}\text { 35. } 2 \\
\text { 36. } 8\end{array}$ & $\begin{array}{l}53.9 \\
73.2\end{array}$ & $\begin{array}{l}\text { 15. } 3 \\
21.4\end{array}$ \\
\hline $\begin{array}{r}0-29 \\
30-34 \\
35-39 \\
40-44 \\
45-49 \\
50-54 \\
55-59 \\
60-64 \\
65-69 \\
70-74 \\
75\end{array}$ & $\begin{array}{r}2.6 \\
16.8 \\
46.0 \\
111.7 \\
274.8 \\
502.8 \\
819.5 \\
1,053.1 \\
1,109.5 \\
1,104.6 \\
867.9\end{array}$ & $\begin{array}{r}\text { 1. } 6 \\
\text { 7. } 9 \\
\text { 17. } 6 \\
28.0 \\
54.8 \\
\text { 81. } 2 \\
\text { 126. } 0 \\
\text { 172. } 7 \\
228.2 \\
279.4 \\
319.0\end{array}$ & $\begin{array}{r}3.9 \\
29.0 \\
55.3 \\
146.4 \\
265.3 \\
495.6 \\
709.3 \\
761.8 \\
586.6 \\
476.0 \\
501.6\end{array}$ & $\begin{array}{r}1.2 \\
8.2 \\
25.6 \\
47.0 \\
68.4 \\
119.4 \\
123.7 \\
153.8 \\
142.7 \\
135.9 \\
181.6\end{array}$ & $\begin{array}{r}2.1 \\
\text { 10. } 5 \\
34.6 \\
66.4 \\
158.1 \\
302.3 \\
453.4 \\
560.6 \\
556.7 \\
570.2 \\
488.9\end{array}$ & $\begin{array}{r}1.3 \\
4.7 \\
9.1 \\
20.1 \\
42.4 \\
59.6 \\
92.0 \\
141.4 \\
185.1 \\
225.3 \\
260.1\end{array}$ & $\begin{array}{r}2.2 \\
19.2 \\
26.2 \\
53.3 \\
108.4 \\
212.6 \\
317.3 \\
311.6 \\
270.8 \\
158.7 \\
255.0\end{array}$ & $\begin{array}{r}0.5 \\
5.3 \\
5.1 \\
\text { 30. } 2 \\
54.0 \\
27.9 \\
79.4 \\
60.1 \\
89.2 \\
133.7 \\
52.6\end{array}$ \\
\hline $\begin{array}{r}0-44 \\
65\end{array}$ and over & $\begin{array}{r}20.1 \\
622.9 \\
1,037.5\end{array}$ & $\begin{array}{r}6.9 \\
102.7 \\
272.3\end{array}$ & $\begin{array}{r}26.2 \\
497.8 \\
535.8\end{array}$ & $\begin{array}{r}9.1 \\
106.6 \\
151.5\end{array}$ & $\begin{array}{r}11.6 \\
348.7 \\
539.0\end{array}$ & $\begin{array}{r}4.0 \\
78.7 \\
221.2\end{array}$ & $\begin{array}{r}8.5 \\
220.6 \\
236.4\end{array}$ & $\begin{array}{l}\text { 3. } 1 \\
\text { 53. } 1 \\
\text { 89. } 6\end{array}$ \\
\hline
\end{tabular}

\begin{tabular}{|c|c|c|c|c|c|}
\hline \multirow{3}{*}{ Age (years) } & \multicolumn{5}{|c|}{ Total } \\
\hline & \multicolumn{2}{|c|}{ White } & \multicolumn{2}{|c|}{ Nonwhite } & \multirow{2}{*}{$\begin{array}{l}\text { All } \\
\text { persons }\end{array}$} \\
\hline & Male & Female & Male & Female & \\
\hline $\begin{array}{l}\text { Total crude rate } \\
\text { Total adjusted rate }{ }^{3}\end{array}$ & $\begin{array}{l}\text { 185. } 6 \\
183.1\end{array}$ & $\begin{array}{l}\text { 46. } 0 \\
\text { 43. } 6\end{array}$ & $\begin{array}{l}103.7 \\
130.6\end{array}$ & $\begin{array}{l}\text { 26. } 3 \\
\text { 34. } 1\end{array}$ & $\begin{array}{l}\text { 110. } 1 \\
110.1\end{array}$ \\
\hline 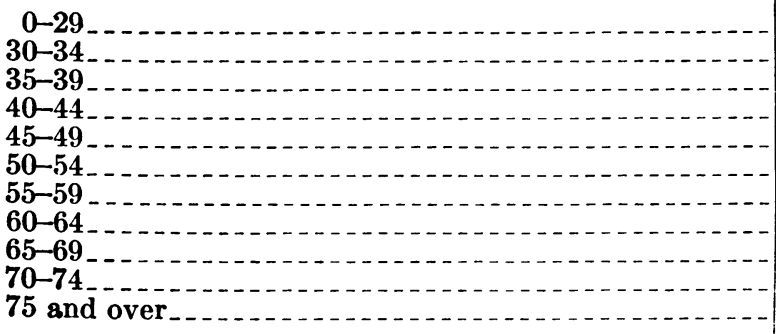 & $\begin{array}{r}2.3 \\
14.3 \\
41.4 \\
93.7 \\
229.5 \\
\text { 427. } 0 \\
679.7 \\
861.3 \\
881.9 \\
874.6 \\
698.0\end{array}$ & $\begin{array}{r}1.5 \\
6.7 \\
14.4 \\
25.1 \\
50.4 \\
73.7 \\
114.0 \\
161.7 \\
212.9 \\
260.2 \\
297.8\end{array}$ & $\begin{array}{r}\text { 3. } 1 \\
\text { 25. } 7 \\
45.4 \\
\text { 114. } 8 \\
211.8 \\
\text { 397. } 3 \\
558.8 \\
\text { 578. } 1 \\
\text { 439. } 1 \\
\text { 320. } 3 \\
\text { 372. } 2\end{array}$ & $\begin{array}{r}0.9 \\
7.3 \\
19.2 \\
41.6 \\
63.8 \\
87.9 \\
107.6 \\
118.4 \\
120.5 \\
135.0 \\
124.5\end{array}$ & $\begin{array}{r}1.9 \\
11.0 \\
28.1 \\
61.0 \\
139.6 \\
249.3 \\
392.9 \\
501.3 \\
515.3 \\
530.5 \\
462.9\end{array}$ \\
\hline $\begin{array}{r}\text { 0-44 } \\
\text { 45-64 } \\
65 \text { and over }\end{array}$ & $\begin{array}{l}\text { 16. } 4 \\
517.6 \\
824.1\end{array}$ & $\begin{array}{r}5.7 \\
94.2 \\
254.0\end{array}$ & $\begin{array}{r}18.4 \\
\text { 397. } 3 \\
\text { 389. } 3\end{array}$ & $\begin{array}{r}6.6 \\
88.0 \\
125.2\end{array}$ & $\begin{array}{l}11.2 \\
300.6 \\
503.1\end{array}$ \\
\hline
\end{tabular}

1 Deaths according to International List Nos. 47b, c, d, and e (1948) and Nos. 162 and 163 (1949); population according to 1950 census. 2 Urban population is generally that living in places of 2,500 and over. 3 Adjusted to the age distribution of the total United States population at the 1950 census. 
Table 3. Cancer of the lung: standardized mortality ratios for the States and regions of the Unifed States, compared with crude mortality ratios, 1948-49

\begin{tabular}{|c|c|c|c|c|c|}
\hline \multirow{2}{*}{ Region and State } & \multicolumn{2}{|c|}{ Number deaths } & \multirow{2}{*}{$\begin{array}{c}\text { Standard- } \\
\text { ized mor- } \\
\text { tality ratio } \\
(\mathrm{SMR})^{1}\end{array}$} & \multirow{2}{*}{$\begin{array}{c}\text { Crude } \\
\text { mortality } \\
\text { ratio } \\
(\mathrm{CMR})\end{array}$} & \multirow{2}{*}{$\begin{array}{l}\text { Ratio: } \\
\text { SMR } \\
\overline{\text { CMR }}\end{array}$} \\
\hline & Observed & Expected & & & \\
\hline United States $\ldots \ldots \ldots$ & 33,180 & 33,181 & 100 & 100 & \\
\hline New England & 2,448 & 2,449 & 100 & 119 & 84 \\
\hline 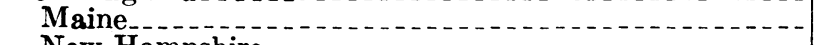 & 174 & 202 & $\dagger 86$ & 86 & 100 \\
\hline New Hampshire $\ldots \ldots$ & 131 & 133 & 98 & 112 & 88 \\
\hline Vermont & 63 & 81 & $† 78$ & 76 & 103 \\
\hline Massachusetts $\ldots \ldots$ & 1,298 & 1,326 & 98 & 126 & 78 \\
\hline $\begin{array}{l}\text { Rhode Island } \\
\text { Connecticut }\end{array}$ & 210 & 212 & 99 & 120 & 82 \\
\hline $\begin{array}{l}\text { Connecticut } \\
\text { Middle Atlantic }\end{array}$ & 572 & $\begin{array}{r}495 \\
765\end{array}$ & $* 115$ & 129 & $\begin{array}{l}89 \\
85\end{array}$ \\
\hline $\begin{array}{l}\text { Middle Atlantic } \\
\text { New York }\end{array}$ & $\begin{array}{l}9,423 \\
5\end{array} 331$ & $\begin{array}{l}7,765 \\
4,005\end{array}$ & $\begin{array}{l}* 121 \\
* 133\end{array}$ & $\begin{array}{l}142 \\
163\end{array}$ & $\begin{array}{l}85 \\
82\end{array}$ \\
\hline 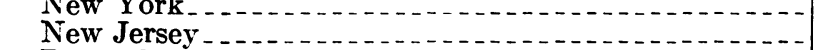 & $\begin{array}{l}5,331 \\
1,509\end{array}$ & & $* 121$ & $\begin{array}{l}103 \\
142\end{array}$ & $\begin{array}{l}82 \\
85\end{array}$ \\
\hline Pennsylvania. & 2,583 & 2,509 & 103 & 112 & 92 \\
\hline South Atlantic & 3,332 & $\overrightarrow{3}, 430$ & 97 & 71 & 137 \\
\hline - & 86 & 66 & $* 131$ & 123 & 106 \\
\hline 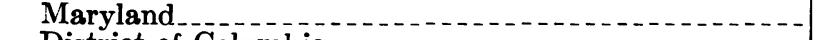 & 575 & 448 & $* 128$ & 111 & 115 \\
\hline District of Columbia & 231 & 189 & $* 122$ & 131 & 93 \\
\hline Virginia _. & 542 & 513 & 106 & 74 & 143 \\
\hline West Virginia & 287 & 338 & *85 & 65 & 131 \\
\hline North Carolina & 400 & 526 & *76 & 45 & 169 \\
\hline & 247 & 247 & 100 & 53 & 189 \\
\hline & 412 & 496 & *83 & 54 & 154 \\
\hline - & 552 & 607 & $\dagger 91$ & 90 & 101 \\
\hline East North Central & 6,851 & 7, 353 & *93 & 102 & 91 \\
\hline Ohio $\ldots \ldots$ & 1,800 & 1,941 & *93 & 103 & 90 \\
\hline Indiana & 746 & 899 & $* 83$ & 86 & 96 \\
\hline Illinois $\ldots \ldots \ldots$ & 2,284 & 2,268 & 101 & 119 & 85 \\
\hline & 1,393 & 1,422 & 98 & 99 & 99 \\
\hline & 628 & 823 & *76 & 83 & 92 \\
\hline & 2,864 & 3,307 & $* 87$ & 92 & 94 \\
\hline & 524 & 711 & $* 74$ & 80 & \\
\hline ( & 459 & 627 & $* 73$ & 80 & 91 \\
\hline $\begin{array}{l}\text { Missouri } \\
\text { North Dakota. }\end{array}$ & 1,056 & 976 & *108 & 121 & 89 \\
\hline & 90 & 113 & †80 & 66 & 121 \\
\hline & 116 & 133 & 87 & 81 & 107 \\
\hline (-10- & 274 & 310 & $\dagger 88$ & 94 & 94 \\
\hline $\begin{array}{l}\text { Kansas } \\
\text { East South Central }\end{array}$ & 345 & 437 & *79 & 82 & 96 \\
\hline $\begin{array}{l}\text { East South Central } \\
\text { Kentucky }\end{array}$ & 1,553 & 1, 799 & $* 86$ & 61 & 141 \\
\hline $\begin{array}{l}\text { Kentucky } \\
\text { Tennessee }\end{array}$ & 425 & 524 & *81 & 66 & 123 \\
\hline $\begin{array}{l}{ }^{\prime} \\
\end{array}$ & 457 & 542 & *84 & 63 & 133 \\
\hline 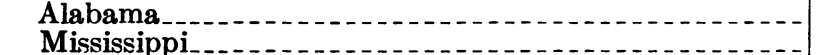 & 402 & 443 & 91 & 60 & 152 \\
\hline $\begin{array}{l}\text { Mississippi } \\
\text { West South Central }\end{array}$ & 269 & 290 & 93 & 56 & 166 \\
\hline $\begin{array}{l}\text { West South Central } \\
\text { Arkansas }\end{array}$ & 2,354 & 2,619 & *90 & 74 & 122 \\
\hline Arkansas $\ldots$ & 199 & 324 & $* 61$ & 47 & 130 \\
\hline Louisiana__... & 603 & 430 & $* 140$ & 102 & 137 \\
\hline Oklahoma $\ldots$ & 364 & 454 & $* 80$ & 74 & 108 \\
\hline 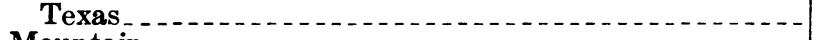 & 1,188 & 1,411 & $* 84$ & 70 & 120 \\
\hline 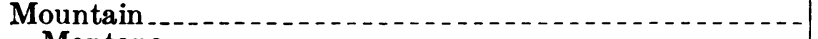 & 843 & 987 & *85 & 75 & 113 \\
\hline Montana & 140 & 134 & 105 & 108 & 97 \\
\hline Idaho $_{-1}$ & 75 & 113 & *66 & 58 & 114 \\
\hline ' & 33 & 57 & *58 & 52 & 112 \\
\hline 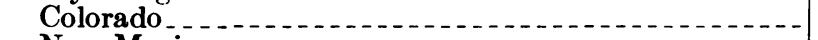 & 246 & 299 & *82 & 84 & 98 \\
\hline New Mexico & 53 & 100 & *53 & 35 & 151 \\
\hline Arizona_-1-1 & 146 & 124 & $\dagger 118$ & 88 & 134 \\
\hline (10, & 108 & 124 & 87 & 71 & 122 \\
\hline$-1-1--1-1-1$ & 42 & 36 & 115 & 119 & 97 \\
\hline$-1-1-1-1-1-1-1$ & 3,512 & 3,472 & 101 & 110 & 92 \\
\hline Washington_ & 494 & 563 & *88 & 94 & 94 \\
\hline Oregon & 350 & 358 & 98 & 104 & 94 \\
\hline California & 2,668 & 2,551 & $\dagger 104$ & 114 & 91 \\
\hline
\end{tabular}

Key. $* \mathrm{P}=0.014$ or less. $\dagger \mathrm{P}=\mathbf{0 . 0 1 5}$ to 0.054 .

1 Apparent discrepancies in some SMR's are due to use of decimals in computations of expected deaths and of SMR and subsequent rounding of figures. A standardized total annual State rate per million population may be obtained by multiplying its SMR by the total United States rate, 110.1. 


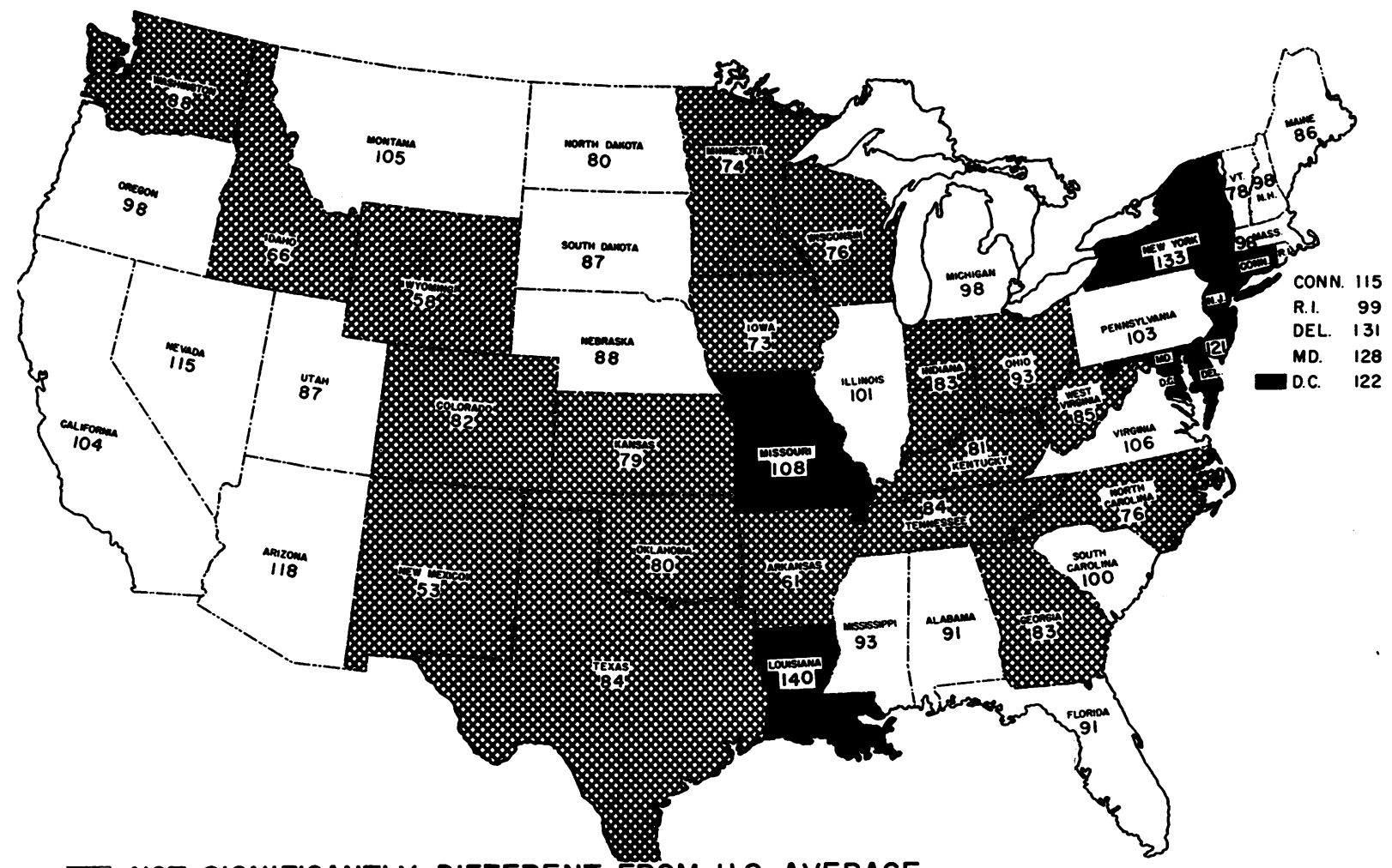

\section{NOT SIGNIFICANTLY DIFFERENT FROM U.S. AVERAGE}

\section{SIGNIFICANTLY ABOVE U.S. AVERAGE SIGNIFICANTLY BELOW U.S. AVERAGE}

for this age differential in rates is apparent. However, it justifies questioning the commonly held belief that the excessive total rate in the white population is due to difference in diagnostic facilities available to the two race groups. It seems unreasonable to believe such facilities would be equal for young adults and not for persons of older ages.

The SMR for each State, computed from the United States rates in table 2, is given in table 3. For comparison, the crude mortality ratio (CMR) is also given. The CMR represents the unadjusted crude State rate expressed as a percentage of the United States total rate. The SMR's are also presented on the accompanying map, and here the States with ratios significantly (at a $\mathbf{P}=0.01$ or less) higher or lower than the United States average are indicated by shading. ( $\mathrm{P}=$ probability that an equal or greater difference between the SMR and the United States average could arise from sampling errors.)
As shown in table 3 and in the map, 8 States and the District of Columbia had significantly higher ratios and 19 States significantly lower ratios. If a $\mathbf{P}=0.05$ were considered significant-but this would appear to be a thin reed on which to lean with data such as these-2 additional States (Arizona and California) would have significantly higher ratios, and 5 additional States (Maine, Vermont, Florida, North Dakota, and Nebraska) would have significantly lower ratios. It should be noted that, although the heavily industrialized States of New York, Connecticut, New Jersey, and Delaware have ratios significantly higher than the United States average, relatively nonindustrial Louisiana has the highest ratio of all and nonindustrial District of Columbia also has a significantly higher ratio. Some other heavily industrialized States, such as Pennsylvania, Ohio, and Michigan, have either average or below average ratios.

The importance of standardization of rates 
Table 4. Cancer of the lung, 1948-49: number of expected deaths and standardized mortality ratios for the race and residence components of each State's population ${ }^{1}$

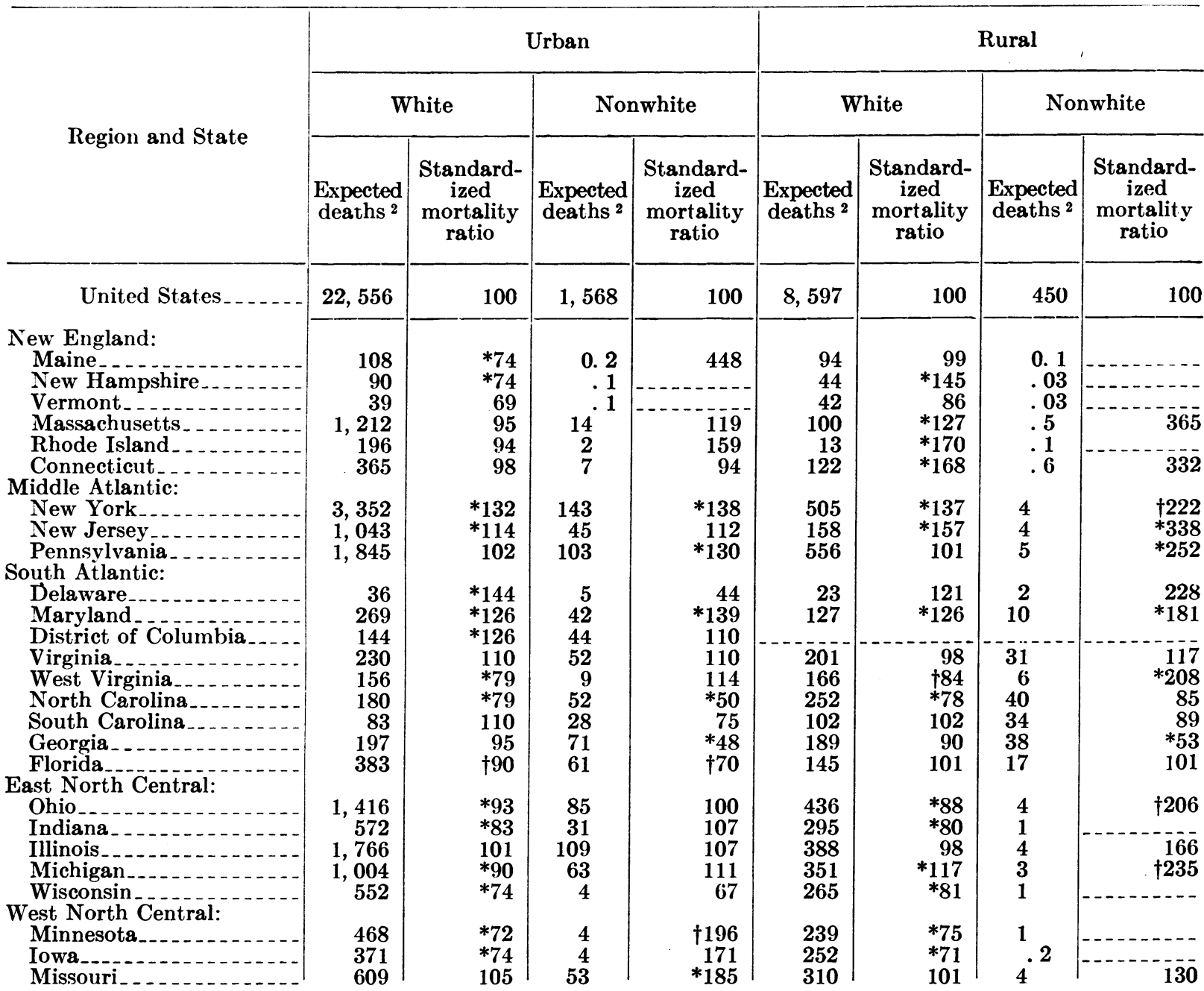

is emphasized in the comparison made in table 3 between the SMR's and the CMR's. Inspection of the ratio between them shows that in general standardization yields SMR's that are lower than the CMR's in the States with large urban and white populations and SMR's that are higher in the more rural States with a large nonwhite population. Unpublished analyses of the effect of different types of rate standardization indicate that in these data standardization for residence and race is more necessary than standardization for age.

The influence of the race and residence population components of each State on its SMR is shown in table 4. The SMR's in this table were computed for the urban and rural portions of the white and nonwhite populations of each
State. Specifically, the number of expected deaths for the white urban population was computed by applying the age and sex specific rates for the urban population of the entire United States to the appropriate State population; the numbers of expected deaths for the other three population groups were similarly derived. (The sum of the expected deaths in the four categories of table 4 should equal the total number given for the expected deaths in each State, as given in table 3. That they do not exactly in each instance is due to use of decimals in computations and subsequent rounding of figures for the tables.)

Taking Louisiana as an example, in all 4 race and residence categories the ratio was greater than the United States average, and in 3 of the 
Table 4. Cancer of the lung, 1948-49: number of expected deaths and standardized mortality ratios for the race and residence components of each State's population ${ }^{1}$ - Continued

\begin{tabular}{|c|c|c|c|c|c|c|c|c|}
\hline \multirow{3}{*}{ Region and State } & \multicolumn{4}{|c|}{ Urban } & \multicolumn{4}{|c|}{ Rural } \\
\hline & \multicolumn{2}{|c|}{ White } & \multicolumn{2}{|c|}{ Nonwhite } & \multicolumn{2}{|c|}{ White } & \multicolumn{2}{|c|}{ Nonwhite } \\
\hline & $\begin{array}{c}\text { Expected } \\
\text { deaths }^{2}\end{array}$ & $\begin{array}{l}\text { Standard- } \\
\text { ized } \\
\text { mortality } \\
\text { ratio }\end{array}$ & $\begin{array}{c}\text { Expected } \\
\text { deaths }^{2}\end{array}$ & \begin{tabular}{|} 
Standard- \\
ized \\
mortality \\
ratio
\end{tabular} & $\begin{array}{c}\text { Expected } \\
\text { deaths }^{2}\end{array} \mid$ & $\begin{array}{l}\text { Standard- } \\
\text { ized } \\
\text { mortality } \\
\text { ratio }\end{array}$ & $\begin{array}{c}\text { Expected } \\
\text { deaths }^{2}\end{array}$ & $\begin{array}{l}\text { Standard- } \\
\text { ized } \\
\text { mortality } \\
\text { ratio }\end{array}$ \\
\hline $\begin{array}{l}\text { West North Central-Con. } \\
\text { North Dakota }\end{array}$ & & & & & & & & \\
\hline $\begin{array}{l}\text { North Dakota } \\
\text { South Dakota }\end{array}$ & $\begin{array}{l}42 \\
59\end{array}$ & +70 & 0. 1 & 264 & $\begin{array}{l}70 \\
72\end{array}$ & 84 & 0.6 & $† 346$ \\
\hline Nebraska. & $\begin{array}{r}59 \\
174\end{array}$ & $\begin{array}{l}171 \\
+85\end{array}$ & $4^{.4}$ & $\begin{array}{l}204 \\
146\end{array}$ & $\begin{array}{r}72 \\
132\end{array}$ & $\begin{array}{r}101 \\
90\end{array}$ & ${ }^{1} .3$ & $-\cdots-\overline{3} \overline{4}$ \\
\hline Kansas & 237 & $* 82$ & 13 & 129 & 184 & $* 71$ & & 128 \\
\hline $\begin{array}{l}\text { East South Central: } \\
\text { Kentucky }\end{array}$ & & & & & & & & \\
\hline $\begin{array}{l}\text { Kentucky } \\
\text { Tennessee }\end{array}$ & 226 & $* 78$ & 28 & $\dagger 139$ & 262 & $* 76$ & 7 & 134 \\
\hline $\begin{array}{l}\text { Tennessee } \\
\text { Alabama }\end{array}$ & 219 & $\dagger 85$ & 62 & ${ }^{* 60}$ & 246 & 92 & 16 & $\dagger 44$ \\
\hline $\begin{array}{l}\text { Alabama } \\
\text { Mississippi }\end{array}$ & $\begin{array}{r}176 \\
89\end{array}$ & 101 & $\begin{array}{r}64 \\
20\end{array}$ & $* 42$ & 165 & 104 & 39 & $\dagger 63$ \\
\hline $\begin{array}{l}\text { Mississippi } \\
\text { West South Central: }\end{array}$ & 82 & 109 & 38 & 69 & 118 & 103 & 52 & $* 59$ \\
\hline Arkansas & 122 & $* 56$ & 28 & $* 51$ & 151 & $* 72$ & 23 & *39 \\
\hline Louisiana & 212 & $* 132$ & 72 & 115 & 113 & $* 164$ & 33 & $* 168$ \\
\hline Oklahoma $\ldots$ & 260 & $* 81$ & 19 & $* 27$ & 169 & 82 & 8 & 106 \\
\hline Texas $_{\text {Mountain. }}$ & 874 & $* 79$ & 101 & 81 & 402 & 94 & 32 & 98 \\
\hline $\begin{array}{l}\text { Mountain: } \\
\text { Montana_. }\end{array}$ & & & & & & & & \\
\hline Idaho & $\begin{array}{l}76 \\
60\end{array}$ & $\begin{array}{l}118 \\
* 68\end{array}$ & .5 & $* 567$ & 56 & 82 & 1 & 190 \\
\hline Wyoming & 36 & $\begin{array}{l}* 68 \\
+62\end{array}$ & $\cdot 4$ & $-\cdots$ & 51 & +66 & $\cdot 5$ & 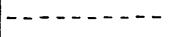 \\
\hline Colorado & 211 & $\begin{array}{l}102 \\
* 80\end{array}$ & $4^{\cdot 4}$ & 23 & 21 & $\begin{array}{r}\dagger 5 \\
93\end{array}$ & $\begin{array}{l}.3 \\
.5\end{array}$ & $-\cdots+\cdots$ \\
\hline New Mexico $\ldots$ & 59 & $* 59$ & $\begin{array}{l}4 \\
1\end{array}$ & 79 & $\begin{array}{l}83 \\
37\end{array}$ & $\begin{array}{l}93 \\
* 46\end{array}$ & $2^{.5}$ & $-\cdots+\cdots$ \\
\hline Arizona & 66 & +125 & 3 & 147 & 50 & 113 & & $6 \overline{\mathbf{2}}$ \\
\hline $\mathrm{Utah}_{\ldots} \ldots \ldots$ & 90 & $\uparrow 78$ & 1 & 228 & 32 & 111 & .4 & $\ldots \ldots$ \\
\hline Nevada $\ldots . . .$. & 24 & 106 & 1 & $\ldots$ & 12 & 146 & .4 & $\ldots \ldots$ \\
\hline Pacific: & & & & & & & & \\
\hline Washington & 381 & $* 82$ & 8 & 78 & 173 & 100 & 1 & 138 \\
\hline Oregon & 227 & 98 & 3 & 205 & 127 & 94 & 1 & 146 \\
\hline California_ & 1,957 & 100 & 85 & 93 & 496 & $* 122$ & 13 & 150 \\
\hline
\end{tabular}

Key: $* \mathrm{P}=\mathbf{0 . 0 1 4}$ or less. $\dagger \mathrm{P}=0.015$ to 0.054 .

1 Apparent discrepancies between this table and table 3 are due to use of decimals in computations and subsequent rounding of figures. 2 Deaths expected if appropriate age specific rates for the United States prevailed. When expected deaths are few, the value of $P$ has little real meaning.

4 it was significantly greater. It is thus seen that the total SMR for Louisiana (140) is contributed to by all race and residence components of the population and is therefore not due alone to an excessive rate in its largest city, New Orleans. The excessive ratios in New York and Maryland are also contributed to by all race and residence components of their populations. In Connecticut, on the other hand, although the urban ratios for both race groups are not significantly different from the average, the excess among white rural residents is sufficiently great to make the total State ratio excessive. In California, although the ratio for the whole State is not significantly different from the United States average, the white rural population of the State has a significantly higher ratio than that of the white rural population of the entire United States. Similar effects are noted in some other States.

Table $t$ also gives an indirect idea of the composition of each State population by race and residence since the deaths expected are directly related to the number of people in each component. It is obvious from table 4, for example, that there are few rural nonwhite residents in Maine, since only 0.1 of a death was expected among them.

\section{Mortality Trend in the States}

In table 5 , the 1930-32 death rates for cancer of the lung and pleura recorded by Gover (1) are compared with the 1948-49 rates for 
Table 5. Death rates per 100,000 population and relative increase in mortality from cancer of the lung among the States, $1930-32$ and $1948-49^{1}$

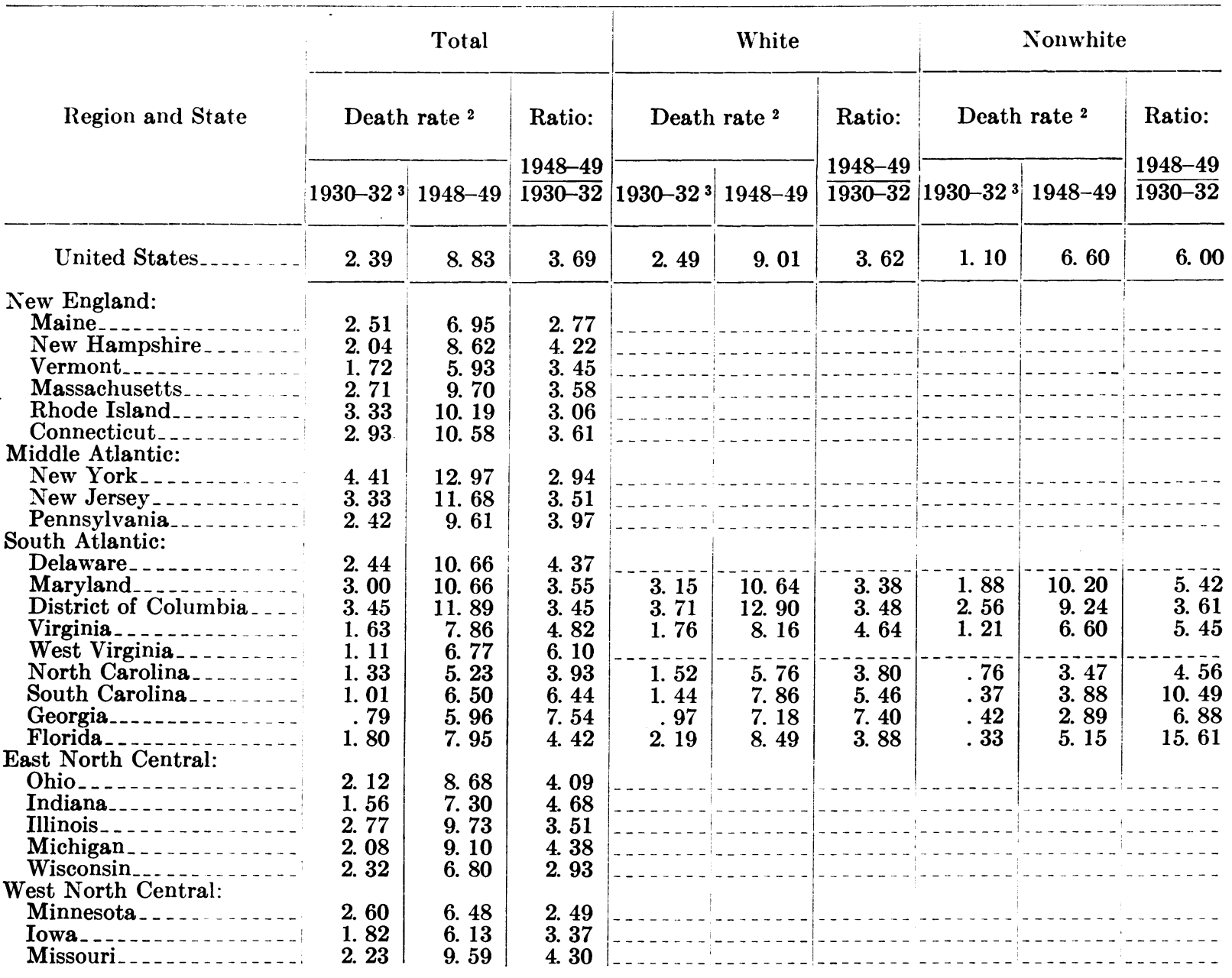

the total population in each State. In addition, the 1930-32 rates for the white and nonwhite populations in the 15 States for which these rates were available are compared with the 1948-49 rates. In these 15 States, the nonwhite population was at least 10,000 or constituted 10 percent or more of the total population. Rates for both periods are standardized to the age distribution of the United States population in 1930 .

Attention should be called to the fact that the rates in table 5 do not permit valid rankorder comparisons between States for either the earlier or later period, since basic data were not available to adjust Gover's data for residence (urban-rural). Thus, the rate in New York for $1948-49$ is given in table 5 as 12.97 and that for Louisiana as 10.63 , although it has already been shown, in table 3 , that the risk of death in Louisiana is numerically greater than in New York when account is taken of the urban-rural influence. The figures in table 5 do, however, permit comparisons among the States in relative increases between the two periods.

Between 1930-32 and 1948-49 mortality attributed to cancer of the lung increased nearly 4 times in the entire United States. The rate for the nonwhite population increased 6 times while the rate for the white population increased only about 4 times. This greater relative increase among the nonwhite population may be due in part to a greater relative increase in urbanization and its concomitants among the nonwhite. Between 1930 and 1950, the percent of the nonwhite population classed as urban 
Table 5. Death rates per 100,000 population and relative increase in mortality from cancer of the lung among the States, $1930-32$ and $1948-49^{1}$-Continued

\begin{tabular}{|c|c|c|c|c|c|c|c|c|c|}
\hline \multirow{3}{*}{ Region and State } & \multicolumn{3}{|c|}{ Total } & \multicolumn{3}{|c|}{ White } & \multicolumn{3}{|c|}{ Nonwhite } \\
\hline & \multicolumn{2}{|c|}{ Death rate $^{2}$} & \multirow{2}{*}{$\begin{array}{l}\text { Ratio: } \\
\frac{1948-49}{1930-32}\end{array}$} & \multicolumn{2}{|c|}{ Death rate ${ }^{2}$} & \multirow{2}{*}{$\begin{array}{l}\text { Ratio: } \\
\frac{1948-49}{1930-32}\end{array}$} & \multicolumn{2}{|c|}{ Death rate ${ }^{2}$} & \multirow{2}{*}{$\begin{array}{l}\text { Ratio: } \\
\frac{1948-49}{1930-32}\end{array}$} \\
\hline & $1930-32^{3}$ & $1948-49$ & & $1930-32^{3}$ & $1948-49$ & & $1930-32^{3}$ & | $1948-49$ & \\
\hline $\begin{array}{l}\text { West North Central-Con. } \\
\text { North Dakota. } \\
\text { South Dakota. } \\
\text { Nebraska. } \\
\text { Kansas }- \\
\text { East South Central: }\end{array}$ & $\begin{array}{l}\text { 1. } 89 \\
\text { 2. } 37 \\
\text { 1. } 99 \\
\text { 1. } 25\end{array}$ & $\begin{array}{l}\text { 6. } 07 \\
6.88 \\
\text { 7. } 44 \\
6.52\end{array}$ & $\begin{array}{l}\text { 3. } 21 \\
2.90 \\
\text { 3. } 74 \\
\text { 5. } 22\end{array}$ & & & & & & \\
\hline $\begin{array}{l}\text { Kentucky } \\
\text { Tennessee } \\
\text { Alabama } \\
\text { Mississippi } \\
\text { West South Central. }\end{array}$ & $\begin{array}{r}.97 \\
1.12 \\
1.16 \\
.74\end{array}$ & $\begin{array}{l}\text { 6. } 28 \\
\text { 6. } 36 \\
\text { 6. } 44 \\
\text { 5. } 90\end{array}$ & $\begin{array}{l}\text { 6. } 47 \\
\text { 5. } 68 \\
\text { 5. } 55 \\
\text { 7. } 97\end{array}$ & $\begin{array}{l}.99 \\
\text { 1. } 16 \\
\text { 1. } 48 \\
1.17\end{array}$ & $\begin{array}{l}\text { 5. } 97 \\
6.87 \\
8.05 \\
\text { 7. } 96\end{array}$ & $\begin{array}{l}\text { 6. } 03 \\
\text { 5. } 92 \\
\text { 5. } 44 \\
6.80\end{array}$ & $\begin{array}{l}.85 \\
.92 \\
.54 \\
.23\end{array}$ & $\begin{array}{l}9.88 \\
\text { 3. } 85 \\
\text { 2. } 74 \\
\text { 3. } 03\end{array}$ & $\begin{aligned} \text { 11. } 62 \\
\text { 4. } 18 \\
\text { 5. } 07 \\
\text { 13. } 17\end{aligned}$ \\
\hline $\begin{array}{l}\text { West South Central: } \\
\text { Arkansas } \\
\text { Louisiana } \\
\text { Oklahoma } \\
\text { Texas }{ }^{4} \text {. }\end{array}$ & $\begin{array}{r}.77 \\
2.31 \\
.95\end{array}$ & $\begin{array}{r}\text { 4. } 58 \\
\text { 10. } 63 \\
6.55 \\
7.02\end{array}$ & $\begin{array}{r}5.95 \\
4.60 \\
6.89\end{array}$ & $\begin{array}{r}.94 \\
\text { 2. } 82 \\
\text { 1. } 03 \\
-\end{array}$ & $\begin{array}{r}5.18 \\
11.99 \\
6.86 \\
7.22\end{array}$ & $\begin{array}{l}5.51 \\
4.25 \\
6.66\end{array}$ & $\begin{array}{r}.19 \\
1.29 \\
.15 \\
\end{array}$ & $\begin{array}{l}\text { 2. } 40 \\
\text { 7. } 72 \\
\text { 3. } 09 \\
\text { 5. } 52\end{array}$ & $\begin{array}{r}12.63 \\
5.98 \\
20.60 \\
\end{array}$ \\
\hline $\begin{array}{l}\text { Mountain: } \\
\text { Montana } \\
\text { Idaho } \\
\text { Wyoming } \\
\text { Colorado } \\
\text { New Mexico } \\
\text { Arizona } \\
\text { Utah } \\
\text { Nevada. } \\
\text { Pacific: }\end{array}$ & $\begin{array}{l}1.82 \\
1.63 \\
1.39 \\
\text { 3. } 02 \\
1.15 \\
2.68 \\
2.64 \\
1.86\end{array}$ & $\begin{array}{r}9.01 \\
5.64 \\
5.23 \\
7.34 \\
4.42 \\
9.49 \\
7.69 \\
10.73\end{array}$ & $\begin{array}{l}\text { 4. } 95 \\
\text { 3. } 46 \\
\text { 3. } 76 \\
\text { 2. } 43 \\
\text { 3. } 84 \\
\text { 3. } 54 \\
\text { 2. } 91 \\
\text { 5. } 77\end{array}$ & 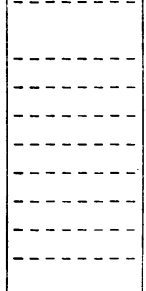 & \begin{tabular}{|}
--1 \\
\hdashline$-1-$ \\
\hdashline$-1-$ \\
-
\end{tabular} & 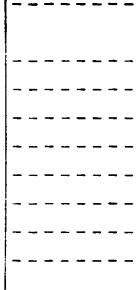 & $\begin{array}{l}-- \\
-- \\
-- \\
-- \\
-- \\
-- \\
--\end{array}$ & 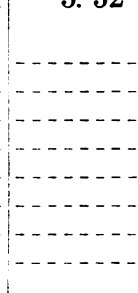 & 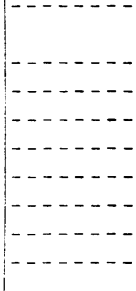 \\
\hline $\begin{array}{l}\text { Pacific: } \\
\text { Washington } \\
\text { Oregon } \\
\text { California. }\end{array}$ & $\begin{array}{l}2.21 \\
2.20 \\
2.96\end{array}$ & $\begin{array}{l}7.80 \\
8.60 \\
9.70\end{array}$ & $\begin{array}{l}\text { 3. } 53 \\
\text { 3. } 91 \\
\text { 3. } 28\end{array}$ & 2.93 & $9.7 \overline{7}$ & $3 . \overline{33}$ & 3.65 & 8.02 & 2.20 \\
\hline
\end{tabular}

1 Since the rates in this table are not adjusted for residence (urban-rural), rank-order comparisons between States are not valid. Only comparisons between the States in relative increases from 1930-32 to 1948-49 can be made with these rates. 2 Rates for both periods are standardized for age to the 1930 census population of the entire United States. ${ }^{3}$ Rates are from Gover (1). 4 Texas did not enter the death registration area until 1933.

increased from 43 to 59 percent, whereas in the white population the increase was only from 56 to 59 percent. It cannot be determined from these data how much of this difference in increase in rates may be attributed to differences in increase in urbanization and its concomitants.

The increase in rates varied from a low of about 2 times in Colorado to a high of about 8 times in Mississippi. Although the calculations are not given, it has been shown that there is a good negative correlation between the 193032 State rates and the relative increase. That is, the States with low rates in the earlier period tended to exhibit a greater relative increase than those with higher rates. There is no similar correlation between the 1948-49 rates and relative increase in rates.

These data do not permit any guess as to how much of the State differences in relative increase might be due to differences in increase in urbanization.

\section{Summary}

Age, race, sex, and residence (urban-rural) specific rates for mortality attributed to cancer of the lung are given for the United States for an average of the years 1948-49. In all age, race, and sex components, the rate is greater for urban residents than for rural residents. The total rates for the white population are considerably higher than those for the nonwhite, but the difference is more pronounced among males than among females. The overall excess among the white population is due to greatly excessive rates among older persons, since in some of the younger age groups rates are actually higher among the non white population. This age dif- 
ferential in rates does not appear to be consistent with the view that the lower total mortality for the nonwhite population is due to inadequate diagnostic facilities.

State rates in 1948-49 are compared by means of standardized mortality ratios. These are ratios standardized for age, race, sex, and residence (urban-rural) and expressed as a percentage of the United States total rate. The influence of the residence and race components of each State population on its total ratio is also demonstrated. It is not possible from data now available here or elsewhere to determine whether the observed geographic distribution is due to environmental, occupational, economic, diagnostic, or other factors.

The increase in lung cancer mortality between 1930-32 and 1948-49 is also shown for the United States and for each State. The increase among the nonwhite population was greater than in the white, but this may be due largely to a greater relative increase in urbanization and its concomitants among the nonwhite population during this period.

\section{REFERENCES}

(1) Gover, M.: Cancer mortality in the United States. III. Geographic variation in recorded cancer mortality for detailed sites, for an average of the years 1930-32. Pub. Health Bull. No. 257. Washington, D. C., U. S. Government Printing Office, 1940.

(2) U. S. Bureau of the Census: Deaths from cancer by place of residence: United States 1935. Vital Statistics, Special Reports, vol. 5, No. 40. Washington, D. C., U. S. Government Printing Office, 1938.

(3) Stocks, P.: Regional and local differences in cancer death rates. Studies on medical and population subjects. No. 1. London, His Majesty's Stationery Office, 1947.

(4) Clemmesen, J., Nielsen, A., and Jensen, E.: Mortality and incidence of cancer of the lung in Denmark and some other countries. Acta Unio Internat. Contra Cancrum 9: 603-636 (1953).

(5) Doll, R.: Bronchial carcinoma: Incidence and aetiology [citing Kreyberg, p. 525]. Brit. Med. J. 4835 : 521-527; 4836: 585-590 (1953).

(6) U. S. National Office of Vital Statistics : Births by race and geographic subdivision: United States, 1950. Vital Statistics, Special Reports, vol. 37, No. 21. Washington, D. C., U. S. Government Printing Office, 1954.

\section{Ask Information on Employee Health Services}

The Occupational Health Branch of the Public Health Service urgently needs information on health maintenance services provided workers in small plants at or through their places of employment. 'This information will aid in developing methods for bringing such services to small establishments.

Management now provides employees of many large industrial organizations with such health services as care of occupational diseases and injuries, health counseling, and periodic health examinations. Regular professional health services of this type, usually given within the plants, are separate and distinct from other management sponsored health activities such as medical insurance plans and medical services given on an on-call-for-emergency basis.

In industrial, commercial, and agricultural establishments of less than 1,000 employees, there is probably a greater coverage of workers than has been publicized. The names and locations of currently operating programs designed for these employees are welcomed. Information is to be sent to: Division of Special Health Services, Occupational Health Branch, Public Health Service, Washington 25, D. C. 